\title{
Streptomyces thermocoprophilus sp. nov., a cellulase-free endo-xylanase-producing streptomycete
}

\author{
Bongcheol Kim, ${ }^{1}$ Amira M. Al-Tai, ${ }^{1,2}$ Seung Bum Kim, ${ }^{1}$ \\ Paramaswari Somasundaram ${ }^{2}$ and Michael Goodfellow ${ }^{1}$
}
1 Department of Agricultural and Environmental Science, University of Newcastle, Newcastle upon Tyne NE1 7RU, UK
2 Institute of Postgraduate Studies and Research, University of Malaya, 50603, Kuala Lumpur, Malaysia

\author{
Author for correspondence: Michael Goodfellow. Tel: +44 191222 7706. Fax: +44 1912225228. \\ e-mail:m.goodfellow@ncl.ac.uk
}

\begin{abstract}
The taxonomic position of a thermophilic actinomycete strain isolated from poultry faeces was examined using a polyphasic approach. The isolate, designated B19', was assigned to the genus Streptomyces on the basis of chemotaxonomic and morphological criteria. An almost complete 16S rRNA gene (rDNA) sequence obtained for the test strain was compared with those of representative streptomycetes, notably thermophilic streptomycetes. $16 \mathrm{~S}$ rDNA sequence data not only supported the assignment of the strain to the genus Streptomyces but also showed that the isolate formed a distinct phyletic line within the evolutionary branch composed of Streptomyces thermodiastaticus and related species. The strain was distinguished from related validly described Streptomyces species by a number of phenotypic properties. It is, therefore, proposed that strain B19' be classified in the genus Streptomyces as Streptomyces thermocoprophilus sp. nov.
\end{abstract}

Keywords: Streptomyces thermocoprophilus sp. nov., thermophilic streptomycetes, polyphasic taxonomy, xylanase production

\section{INTRODUCTION}

Most thermophilic streptomycetes grow well at $50{ }^{\circ} \mathrm{C}$ and over the temperature range $25-55^{\circ} \mathrm{C}$. Representatives of these organisms have been distinguished from their better known mesophilic counterparts in numerical phenetic (Goodfellow et al., 1987; O'Donnell et al., 1993) and 16S rRNA sequencing studies (D. Kim et al., 1996; S. B. Kim et al., 1998; B. Kim et al., 1999). It is apparent from the sequencing studies that thermophilic streptomycetes form at least two evolutionary clades and hence cannot be considered as a distinct taxon within the genus Streptomyces as proposed by Craveri \& Pagani (1962). It is also clear that novel streptomycete species should be circumscribed using a judicious combination of genotypic and phenotypic data (Labeda et al., 1997; S. B. Kim et al., 1998; Miyajima et al., 1998; B. Kim et al., 1999).

Streptomycetes are a rich source of bioactive compounds, notably antibiotics, enzymes, enzyme in-

Abbreviation: $\mathrm{A}_{2} \mathrm{pm}$, diaminopimelic acid.

The EMBL accession number for the $16 \mathrm{~S}$ rRNA sequence of strain $\mathrm{B}^{\mathrm{B}} \mathrm{9}^{\mathrm{T}}$ is AJ007402. hibitors and pharmacologically active agents (Bérdy, 1995). In a search for xylanase producing bacteria, a streptomycete-like organism, strain $\mathrm{B} 19^{\mathrm{T}}$, was isolated from poultry faeces and shown to produce a cellulasefree endo-xylanase. In the present investigation, this organism was the subject of a polyphasic taxonomic study which showed that it formed a new centre of taxonomic variation within the genus Streptomyces.

\section{METHODS}

Organism and cultural conditions. Strain $\mathrm{B} 19^{\mathrm{T}}$ was isolated on a yeast extract starch agar plate (Somasundaram, 1995), supplemented with nystatin $\left(20 \mu \mathrm{g} \mathrm{ml}^{-1}\right)$, which had been inoculated with a suspension of poultry faeces and incubated at $45^{\circ} \mathrm{C}$ for $2-3 \mathrm{~d}$; the faeces sample was obtained from the poultry farm at the University of Malaya. The isolate was maintained on inorganic salt-starch agar (ISP medium 4, Difco; Shirling \& Gottlieb, 1966) at room temperature and as spore and hyphal suspensions in glycerol $(20 \%, \mathrm{v} / \mathrm{v})$ at $-20^{\circ} \mathrm{C}$. Biomass for the chemotaxonomic and molecular systematic analyses was prepared as described by B. Kim et al. (1999). The phenotypic tests were carried out at $45^{\circ} \mathrm{C}$ for $7 \mathrm{~d}$.

Morphology and pigmentation. Aerial spore mass colour, substrate mycelial pigmentation and the production of soluble pigments were detected on standard media (Table 1) 
following incubation at $45^{\circ} \mathrm{C}$ for $7 \mathrm{~d}$. Spore chain morphology and spore surface ornamentation were examined by scanning electron microscopy, as described previously (O’Donnell et al., 1993).

Phenotypic tests. Strain B19 ${ }^{\mathrm{T}}$ was examined for a set of phenotypic properties using procedures described in a previous study (Al-Tai et al., 1999). Xylanase production was detected using Czapek Dox agar (Oxoid) supplemented with remazol brilliant blue R-xylan (Sigma) after incubation for $7 \mathrm{~d}$ following the procedure of Biely et al. (1985).

Chemotaxonomy. The isomeric form of diaminopimelic acid $\left(\mathrm{A}_{2} \mathrm{pm}\right)$ was determined by TLC of whole-organism hydrolysates after Staneck \& Roberts (1974). Standard procedures were also used for the extraction and analysis of menaquinones and polar lipids (Minnikin et al., 1984), as described by Chun et al. (1997a). The presence of mycolic acids was sought using the method described by Minnikin et al. (1980).

Sequencing of $16 \mathrm{~S}$ rDNA. Isolation of chromosomal DNA and PCR amplification of $16 \mathrm{~S}$ rDNA were carried out after Chun \& Goodfellow (1995). The amplified fragment was purified by gel electrophoresis and directly sequenced by using a Taq DyeDeoxy Terminator cycle sequencing kit (Applied Biosystems) and previously described primers (Chun \& Goodfellow, 1995). Sequencing gel electrophoresis was carried out and the nucleotide sequences automatically obtained by using an Applied Biosystems DNA sequencer (model 373A) and software provided by the manufacturer.

Analysis of sequence data. The $16 \mathrm{~S}$ rDNA sequences were aligned manually with available streptomycete nucleotide sequences retrieved from the Ribosomal Database Project (Maidak et al., 1997) and the EMBL/GenBank databases by using the AL16S program (Chun, 1995). Evolutionary trees were inferred by using three treeing algorithms, namely, the least-squares (Fitch \& Margoliash, 1967), maximum-likelihood (Felsenstein, 1981) and neighbour-joining (Saitou \& Nei, 1987) methods. Evolutionary distance matrices for the least-squares and maximum-likelihood methods were prepared as described by Jukes \& Cantor (1969). The PHYLIP package (Felsenstein, 1993) was used with all three algorithms. The resultant tree topologies were evaluated by carrying out bootstrap analyses (Felsenstein, 1985) of the neighbour-joining data based on 1000 re-samplings using the SEQBOOT and CONSENSE programs in the PHYLIP package (Felsenstein, 1993). The root position of the tree based on the least-squares method was estimated using the $16 \mathrm{~S}$ rRNA sequence of Arthrobacter globiformis (DSM 20214 ) as outgroup.

DNA base composition. The base composition of the genomic DNA of the test strain was determined as described by S. B. Kim et al. (1998).

\section{RESULTS AND DISCUSSION}

The chemical and morphological properties of strain $\mathrm{B} 19^{\mathrm{T}}$ are consistent with its assignment to the genus Streptomyces (Williams et al., 1989; Manfio et al., 1995). The organism forms an highly branched substrate mycelium, aerial hyphae which carry smooth surfaced spores $(1.1 \sim 1.7 \times 0.5 \mu \mathrm{m})$ in straight chains, contains LL- $\mathrm{A}_{2} \mathrm{pm}$ in the peptidoglycan, lacks characteristic sugars and mycolic acids, has tetra-, hexa- and octahydrogenated (the most abundant) menaquinones with nine isoprene units, contains diphosphatidylglycerol, phosphatidylethanolamine, phosphatidylinositol and phosphatidylinositol mannosides as typical polar lipids, and has a DNA base composition of $68.6 \mathrm{~mol} \% \mathrm{G}+\mathrm{C}$. The assignment of the strain to the genus Streptomyces is also supported by $16 \mathrm{~S}$ rDNA sequence data.

Comparison of the almost complete $16 \mathrm{~S}$ rDNA sequence (1492 nucleotides) of the test strain with corresponding streptomycete sequences showed that strain $\mathrm{B} 19^{\mathrm{T}}$ lies at the periphery of the evolutionary clade occupied by Streptomyces thermodiastaticus and allied taxa in the trees generated using the leastsquares, maximum-likelihood and neighbour-joining algorithms (Fig. 1). The mean 16S rDNA similarity value found between the test strain and members of the S. thermodiastaticus clade was $97 \cdot 9 \%$. Strain B19 shares particularly high percentage nucleotide sequence similarities with Streptomyces thermoviolaceus subsp. apingens $(98.6 \%)$ and Streptomyces thermoviolaceus subsp. thermoviolaceus $(98.2 \%)$; these values correspond to 21 and 27 nucleotide differences out of 1475 nucleotide positions. Nucleotide similarities within this range have been reported for several validly described species belonging to the $S$. thermodiastaticus clade, for instance, between Streptomyces thermocarboxydovorans and Streptomyces thermoviolaceus $(98.8 \%$; S. B. Kim et al., 1998). Members of these taxa form distinct genomic species and can be separated using a set of phenotypic properties (Goodfellow et al., 1987; B. Kim et al., 1999).

Strain $\mathrm{B} 19^{\mathrm{T}}$ forms a brown substrate mycelium, a grey aerial spore mass and brown diffusible pigments on several standard media (Table 1). It also produces melanin pigments on peptone iron and tyrosine agars. The organism can be distinguished from members of the $S$. thermodiastaticus clade using a combination of phenotypic properties (Table 2). This latter observation is in line with recent studies which show that members of streptomycete species found to be closely related on the basis of genotypic data can also be distinguished using phenotypic properties, notably morphological and pigmentation features (Labeda \& Lyons, 1991; Chun et al., 1997b; Labeda et al., 1997; S. B. Kim et al., 1998).

It is apparent from the genotypic and phenotypic data that strain $\mathrm{B} 19^{\mathrm{T}}$ forms a distinct centre of taxonomic variation within the genus Streptomyces. It is proposed, therefore, that this organism be recognized as a new species of the genus Streptomyces, namely, Streptomyces thermocoprophilus sp. nov.

\section{Description of Streptomyces thermocoprophilus sp. nov.}

Streptomyces thermocoprophilus (ther.mo.co.pro. phi'lus. Gr. n. therme heat; Gr. n. copro dung; Gr. adj. philus loving; M.L. adj. thermocoprophilus dungloving thermophile). 


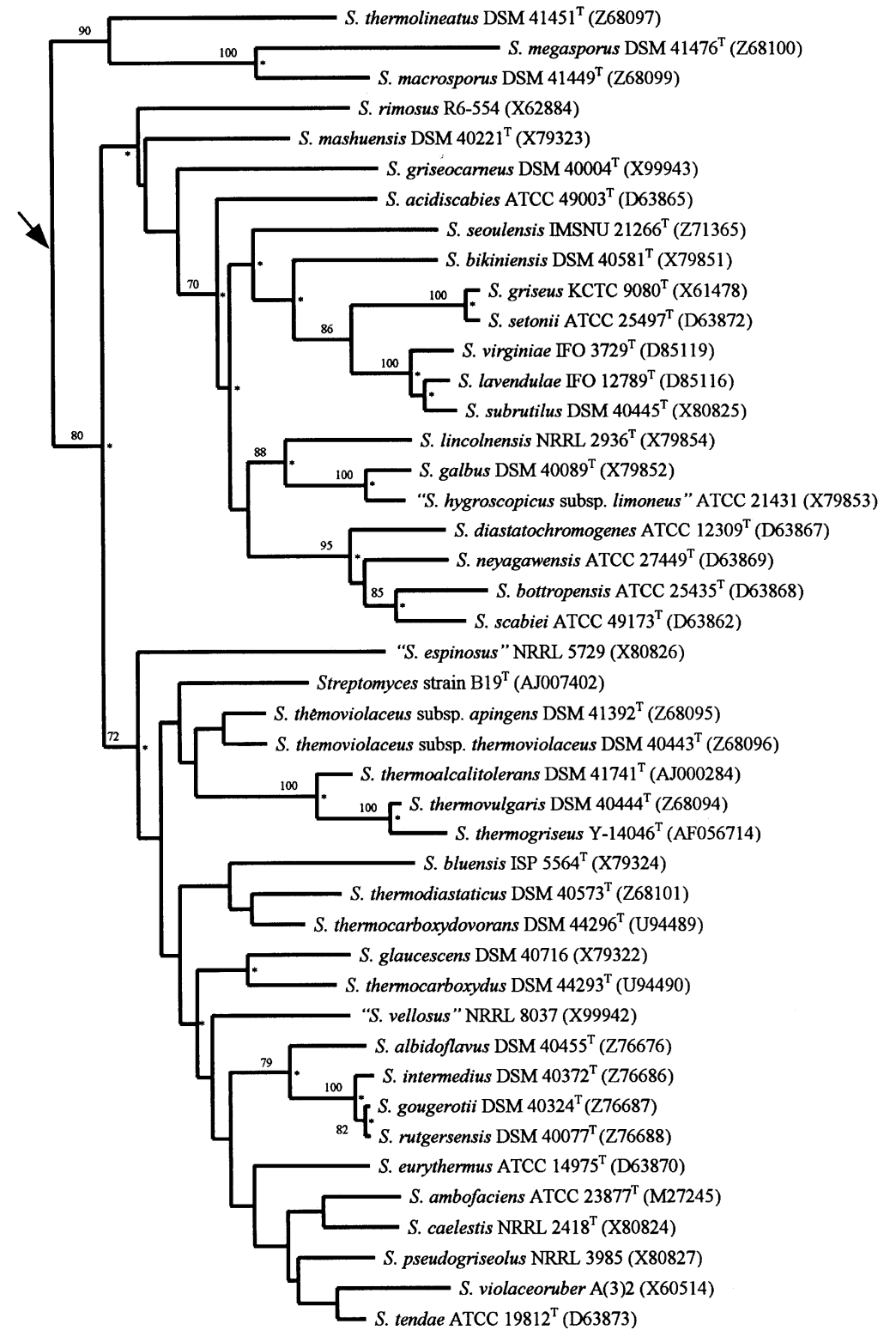

Fig. 1. Neighbour-joining tree (Saitou \& Nei, 1987) based on nearly complete $16 \mathrm{~S}$ rRNA sequences of 44 streptomycetes. Asterisks indicate branches of the tree that were also formed using the maximum-likelihood (Felsenstein, 1981) and neighbour-joining (Saitou \& Nei, 1987) methods. Numbers at the nodes indicate the levels of bootstrap support based on a neighbour-joining analysis of 1000 resampled datasets; only values more than $70 \%$ are given. Arrow indicates the estimated position of the root of the tree. Scale bar indicates 0.01 nucleotide substitutions per nucleotide position. T, type strain.

Table 1. Growth and cultural characteristics of strain $B 19^{\top}$

\begin{tabular}{|lllll|}
\hline Agar medium & Growth & Aerial hyphae & Substrate mycelium & Soluble pigment \\
\hline Modified Bennett's & Moderate & None & Pale brown & None \\
Czapek Dox & Abundant & None & Brown & Brown \\
Glycerol-asparagine (ISP medium 5) & Abundant & Grey & Light yellow & None \\
Inorganic salts-starch (ISP medium 4) & Abundant & Grey & Light yellow & None \\
Oatmeal (ISP medium 3) & Abundant & Grey & Not distinctive & None \\
Peptone-yeast extract-iron (ISP medium 6) & Abundant & None & Pale brown & Brown \\
Starch-casein & Abundant & Grey & Not distinctive & None \\
Yeast extract-malt extract (ISP medium 2) & Abundant & Grey & Brown & Brown \\
\hline
\end{tabular}

Aerobic, Gram-positive, moderately thermophilic actinomycete which forms a highly branched substrate mycelium and aerial hyphae which differentiate into long chains of straight spores which are cylindrical and have smooth surfaces $(1 \cdot 1 \sim 1.7 \times 0.5 \mu \mathrm{m})$. The aerial spore mass colour is grey. Diffusible pigments are 
Table 2. Phenotypic properties separating the test strain from related Streptomyces species

Strains: 1, Streptomyces strain B19 $; 2$, S. thermoalcalitolerans DSM 41741 ${ }^{\mathrm{T}} ; 3$, S. thermocarboxydovorans DSM 44296 ${ }^{\mathrm{T}} ; 4$, S. thermocarboxydus DSM $44293^{\mathrm{T}}$; 5, S. thermodiastaticus DSM 40573 ${ }^{\mathrm{T}} ; 6$, S. thermoviolaceus subsp. thermoviolaceus DSM $40443^{\mathrm{T}}$; 7, S. thermoviolaceus subsp. apingens DSM 41392 $; 8$, S. thermovulgaris. Abbreviations: RA, retinaculiaperti; RF, rectiflexibiles; SP, spirales. Symbols: +, positive or more than $90 \%$ of strains positive in the case of the $S$. thermocarboxydovorans, $S$. thermogriseus and $S$. thermovulgaris strains; -, negative or more than $90 \%$ of strains negative in the case of the $S$. thermocarboxydovorans, $S$. thermogriseus and $S$. thermovulgaris strains. ND, Not determined; v, variable. All strains had grey aerial spore mass; results were ' + ' for starch degradation and growth at 25 and $50{ }^{\circ} \mathrm{C}$; results were ' - ' for growth at 10,15 and $60{ }^{\circ} \mathrm{C}$.

\begin{tabular}{|c|c|c|c|c|c|c|c|c|}
\hline \multirow[t]{2}{*}{ Property } & \multicolumn{8}{|c|}{ Strain: } \\
\hline & 1 & 2 & $3^{*}$ & 4 & $5^{*}$ & $6^{*}$ & 7* & 8 \\
\hline $\begin{array}{l}\text { Pigmentation of substrate } \\
\text { mycelium on oatmeal agar }\end{array}$ & Not distinctive & Not distinctive & Not distinctive & Not distinctive & Yellowish brown & Yellow/purple $\dagger$ & Yellow & Not distinctive \\
\hline Spore chain & RF & SP & $\mathrm{RF}$ & RA & SP & SP & SP & SP \\
\hline Spore surface & Smooth & Warty & Smooth & Warty & Tuberculate & Tuberculate & Tuberculate & Smooth \\
\hline Melanin production & + & - & - & - & - & - & - & - \\
\hline Nitrate reduction & ND & + & + & + & - & - & - & + \\
\hline \multicolumn{9}{|l|}{ Degradation of: } \\
\hline Adenine & - & - & + & $\mathrm{ND}$ & + & + & + & $\mathrm{v}$ \\
\hline Casein & + & + & $\mathrm{ND}$ & $\mathrm{ND}$ & + & + & $\mathrm{ND}$ & + \\
\hline Elastin & - & - & + & + & + & + & + & + \\
\hline Gelatin & + & + & - & + & + & + & + & + \\
\hline Hypoxanthine & + & - & + & + & - & - & + & - \\
\hline Testosterone & - & + & + & + & + & - & - & $\mathrm{v}$ \\
\hline L-Tyrosine & + & + & + & - & + & + & + & + \\
\hline Xanthine & + & - & + & + & - & - & - & - \\
\hline Xylan & + & + & + & - & - & - & - & - \\
\hline \multicolumn{9}{|l|}{$\begin{array}{l}\text { Growth on sole carbon } \\
\text { sources: }\end{array}$} \\
\hline L-Arabinose & + & + & - & $\mathrm{ND}$ & - & - & + & - \\
\hline meso-Inositol & + & + & - & + & + & + & + & + \\
\hline Mannitol & + & + & - & + & + & + & + & + \\
\hline Raffinose & - & - & - & - & + & - & - & - \\
\hline Sucrose & - & + & - & - & - & - & + & + \\
\hline \multicolumn{9}{|l|}{ Growth at: } \\
\hline $20{ }^{\circ} \mathrm{C}$ & + & - & + & + & - & + & + & - \\
\hline $55^{\circ} \mathrm{C}$ & - & + & + & + & + & + & + & + \\
\hline
\end{tabular}

* Data taken from previous studies (Shirling \& Gottlieb, 1969, 1972; Williams et al., 1983; Goodfellow et al., 1987; S. B. Kim et al., 1998; B. Kim et al., 1999; Xu et al., 1998).

$\uparrow$ Substrate mycelium is initially yellow but becomes purple after $5 \mathrm{~d}$ due to the formation of a diffusible purple pigment.

formed on some standard media such as inorganic salts starch agar. Melanin pigments are produced on peptone iron and tyrosine agars. Casein, starch, xanthine and xylan are degraded but not adenine. LArabinose, D-fructose, D-galactose, D-glucose, mesoinositol, maltose, D-mannitol, D-mannose and D-xylose are used as sole carbon sources for energy and growth but not carboxymethylcellulose, D-raffinose, starch or sucrose. Growth occurs between 20 and $50{ }^{\circ} \mathrm{C}$ and in the presence of ampicillin $\left(10 \mu \mathrm{g} \mathrm{ml}^{-1}\right)$, erythromycin $\left(15 \mu \mathrm{g} \mathrm{ml}^{-1}\right)$ and sodium chloride $(7 \%, \mathrm{w} / \mathrm{v})$ but not at 10 or $55^{\circ} \mathrm{C}$. Growth is inhibited by chloramphenicol $\left(30 \mu \mathrm{g} \mathrm{ml}^{-1}\right)$, gentamicin sulphate $\left(15 \mu \mathrm{g} \mathrm{ml}^{-1}\right)$, kanamycin sulphate $\left(30 \mu \mathrm{g} \mathrm{ml}^{-1}\right)$, neomycin sulphate $(30 \mu \mathrm{g}$ $\left.\mathrm{ml}^{-1}\right)$, streptomycin sulphate $\left(10 \mu \mathrm{g} \mathrm{ml}^{-1}\right)$ and tetracycline hydrochloride $\left(30 \mu \mathrm{g} \mathrm{ml}^{-1}\right)$. Antimicrobial activity is shown against Bacillus subtilis NCIB 3610 but not towards Escherichia coli NCIB 9132 or Staphylococcus aureus ATCC 12600, or against representative strains of Candida albicans, Curvularia lunata, Pestalotiopsis gnepini, Pyricularia oryzae and Trichoderma viride. The $\mathrm{G}+\mathrm{C}$ content of the genomic DNA is
$68 \cdot 6 \mathrm{~mol} \%$. The organism was isolated from a sample of poultry faeces collected from the poultry farm at the University of Malaya. The type strain is $\mathrm{B} 19^{\mathrm{T}}(=$ DSM $41700^{\mathrm{T}}$ ).

It is also evident from the phylogenetic tree that $S$. thermogriseus $\mathrm{Y}-14046^{\mathrm{T}}$ and $S$. thermovulgaris DSM $40444^{\mathrm{T}}$ are closely related. These strains show a similarity of $99.5 \%$, which corresponds to seven differences out of 1445 nucleotides. However, all of the differences occur in the conserved regions of the $16 \mathrm{~S}$ rDNA. Further comparative studies are needed to determine the relationship between these two strains.

\section{ACKNOWLEDGEMENTS}

B.K. was supported by an Overseas Research Student Award and S. B. K. by a Chevening-Most Scholarship. A. AT. gratefully acknowledges receipt of a Postdoctoral Grant from the Ministry of Science and Technology, Malaysia and is indebted to Professor Dato Osman Baker (University of Malaya) for supporting her visit to the University of Newcastle. The work was also supported by BBSRC grant 
R185/05688/01. The authors are also grateful to Professor V. G. Kumar Das (University of Malaya) for the gift of fungal cultures and to Professor D. E. Minnikin for help with the polar lipid analysis.

\section{REFERENCES}

Al-Tai, A. M., Kim, B., Kim, S. B., Manfio, G. P. \& Goodfellow, M. (1999). Streptomyces malaysiensis sp. nov., a new streptomycete species with rugose ornamented spores. Int J Syst Bacteriol 49, 1395-1402.

Bérdy, J. (1995). Are actinomycetes exhausted as a source of secondary metabolites? Biotechnologia 7-8, 13-34.

Biely, P., Mislovicova, D. \& Toman, R. (1985). Soluble chromogenic substrates for assay of endo-1,4-xylanases and endo1,4-glucanases. Anal Biochem 144, 142-146.

Chun, J. (1995). Computer-assisted classification and identification of actinomycetes. $\mathrm{PhD}$ thesis, University of Newcastle upon Tyne.

Chun, J. \& Goodfellow, M. (1995). A phylogenetic analysis of the genus Nocardia with 16S rRNA gene sequences. Int $J$ Syst Bacteriol 45, 240-245.

Chun, J., Blackall, L., Kang, S.-O., Hah, Y. C. \& Goodfellow, M. (1997a). A proposal to reclassify Nocardia pinensis Blackall et al. as Skermania piniformis gen. nov., comb. nov. Int J Syst Bacteriol 47, 127-131.

Chun, J., Youn, H.-D., Yim, Y.-I., Lee, H., Kim, M. Y., Hah, Y. C. \& Kang, S.-O. (1997b). Streptomyces seoulensis sp. nov. Int J Syst Bacteriol 47, 492-498.

Craveri, R. \& Pagani, H. (1962). Thermophilic micro-organisms among actinomycetes in the soil. Ann Microbiol 12, 115-130.

Felsenstein, J. (1981). Evolutionary tree from DNA sequences: a maximum likelihood approach. J Mol Evol 17, 368-376.

Felsenstein, J. (1985). Confidence limits on phylogeny: an approach using the bootstrap. Evolution 39, 783-791.

Felsenstein, J. (1993). PHYLIP (phylogenetic inference package), version 3.5c. Seattle: Department of Genetics, University of Washington, USA.

Fitch, W. M. \& Margoliash, E. (1967). Construction of phylogenetic trees: a method based on mutation distances as estimated from cytochrome $c$ sequences is of general applicability. Science 155, 279-284.

Goodfellow, M., Lacey, J. \& Todd, C. (1987). Numerical classification of thermophilic streptomycetes. J Gen Microbiol 133, 3135-3149.

Jukes, T. H. \& Cantor, C. R. (1969). Evolution of protein molecules. In Mammalian Protein Metabolism, vol. 3, pp. 21-132. Edited by H. N. Munro. New York: Academic Press.

Kim, B., Sahin, N., Minnikin, D. E., Zakrzewska-Czerwinska, J., Mordarski, M. \& Goodfellow, M. (1999). Classification of thermophilic streptomycetes including the description of Streptomyces thermoalcalitolerans. Int J Syst Bacteriol 49, 7-17.

Kim, D., Chun, J., Sahin, N., Hah, Y.-C. \& Goodfellow, M. (1996). Analysis of thermophilic clades within the genus Streptomyces by $16 \mathrm{~S}$ ribosomal DNA sequence comparisons. Int $J$ Syst Bacteriol 46, 581-587.

Kim, S. B., Falconer, C., Williams, E. \& Goodfellow, M. (1998). Streptomyces thermocarboxydovorans sp. nov. and Streptomyces thermocarboxydus sp. nov., two moderately thermo- philic carboxydotrophic species from soil. Int $J$ Syst Bacteriol 48, 59-68.

Labeda, D. P. \& Lyons, A. J. (1991). Deoxyribonucleic acid relatedness among species of the Streptomyces cyaneus cluster. Syst Appl Microbiol 14, 158-164.

Labeda, D. P., Lechevalier, M. P. \& Testa, R. T. (1997). Streptomyces stramineus $\mathrm{sp}$. nov. a new species of the verticillate streptomycetes. Int J Syst Bacteriol 47, 747-753.

Maidak, B. L., Olsen, G. J., Larsen, N., Overbeek, R., McCaughey, M. J. \& Woese, C. R. (1997). The Ribosomal Database Project (RDP). Nucleic Acids Res 5, 109-111.

Manfio, G. P., Zakrzewska-Czerwinska, J., Atalan, E. \& Goodfellow, M. (1995). Towards minimal standards for the description of Streptomyces species. Biotechnologia 7-8, 242-253.

Minnikin, D. E., Hutchinson, I. G., Caldicott, A. B. \& Goodfellow, M. (1980). Thin-layer chromatography of methanolysates of mycolic acid-containing bacteria. J Chromatogr 188, 221-233.

Minnikin, D. E., O’Donnell, A. G., Goodfellow, M., Alderson, G., Athayle, M., Schaal, A. \& Parlett, J. H. (1984). An integrated procedure for the extraction of bacterial isoprenoid quinones and polar lipids. J Microbiol Methods 2, 233-241.

Miyajima, K., Tanaka, F., Takeuchi, T. \& Kuninaga, S. (1998). Streptomyces turgidiscabies sp. nov. Int J Syst Bacteriol 48, 495-502.

O'Donnell, A. G., Falconer, C., Goodfellow, M., Ward, A. C. \& Williams, E. (1993). Biosystematics and diversity amongst novel carboxydotrophic actinomycetes. Antonie Leeuwenhoek 64, 325-340.

Saitou, N. \& Nei, M. (1987). The neighbor-joining method: a new method for reconstructing phylogenetic trees. Mol Biol Evol 4, 406-425.

Shirling, E. B. \& Gottlieb, D. (1966). Methods for characterization of Streptomyces species. Int J Syst Bacteriol 16, 313-340.

Shirling, E. B. \& Gottlieb, D. (1969). Cooperative description of type cultures of Streptomyces. IV. Species descriptions from the second, third and fourth studies. Int J Syst Bacteriol 19, 391-512.

Shirling, E. B. \& Gottlieb, D. (1972). Cooperative description of type strains of Streptomyces. V. Additional descriptions. Int $J$ Syst Bacteriol 22, 265-394.

Somasundaram, P. (1995). Studies on xylanase from Streptomyces noboritoensis and Myceliophthora thermophila. $\mathrm{PhD}$ thesis, University of Malaya.

Staneck, J. L. \& Roberts, G. D. (1974). Simplified approach to identification of aerobic actinomycetes by thin-layer chromatography. Appl Microbiol 28, 226-231.

Williams, S.T., Goodfellow, M., Alderson, G., Wellington, E. M. H., Sneath, P. H. A. \& Sackin, M. J. (1983). Numerical classification of Streptomyces and related genera. J Gen Microbiol 129, 1743-1813.

Williams, S. T., Goodfellow, M. \& Alderson, G. (1989). Genus Streptomyces Waksman and Henrici, 1943, 339 ${ }^{\mathrm{AL}}$. In Bergey's Manual of Systematic Bacteriology, volume 4, pp. 2452-2492. Edited by S. T. Williams, M. E. Sharpe \& J. G. Holt. Baltimore: Williams \& Wilkins.

Xu, L.-H., Tiang, Y.-Q., Zhang, Y.-F., Zhou, L.-X. \& Jiang, C.-L. (1998). Streptomyces thermogriseus, a new species of the genus Streptomyces from soil, lake and hot spring. Int J Syst Bacteriol 48, 1089-1093. 